\title{
The Prevalence and Determinants of Anaemia among Clients of the AIDS Support Organisation-Entebbe, Uganda
}

\author{
Lydia Nakyeyune $^{1}$, Edward Mukooza Kibikyo ${ }^{1 *}$, Henry Sseguya ${ }^{1}$, Ekiria Kikule ${ }^{1}$ \\ ${ }^{1}$ Department of Public Health, Uganda Christian University, Uganda
}

\begin{abstract}
Anaemia, a common hematological disorder in HIV infection, compromises the quality of life and treatment outcomes. At The AIDS Support Organisation (TASO), Entebbe, the records for the 20162018 period show a 10\% prevalence of anaemia which is lower than that in literature where it is said to be up to 95\%. This study determined the prevalence, type, severity, and determinants of anaemia among people living with HIV and AIDS who receive care from TASO Entebbe in Uganda. A questionnaire was used to collect data from 624 TASO clients. A checklist identified the clients' Antiretroviral Therapy (ART) combination and viral load. The selected clients' Body Mass Index (BMI) was calculated to assess their nutritional status. A Fully Automated Humacount 60TS ThreePart Hematology Analyzer was used to measure hemoglobin and to do a full blood count. A blood film from each sample was manually examined for the type of anaemia. Data analysis was done with Stata MP 15. The prevalence of anaemia was $44.4 \%$, and the anaemia was mostly mild (54.15\%) to moderate (40.80\%). Anaemia of inflammation was the commonest type (>58\%). Gender, viral suppression, nutritional status, nutritional education, marital and economic status were significantly associated with the anaemia. Duration on ART had a protective effect, but this was not statistically significant. The prevalence of anaemia (44.4\%) among the TASO-Entebbe Uganda clients was high, but the anaemia was mostly mild to moderate (>94\%) and of inflammation type (>58\%). Management of anaemia in HIV requires intentional screening since it compromises treatment outcomes.
\end{abstract}

Keywords: Prevalence of anaemia in HIV, Determinants of anaemia in HIV, Uganda, TASO.

\section{Introduction}

Anaemia is defined by the World Health Organisation as "a condition in which the number of red blood cells (and consequently their oxygen-carrying capacity) is insufficient to meet the body's physiologic needs" [1]. The red blood cells carry a protein, haemoglobin, that has the oxygen-carrying capacity, and it is used as an indicator for anaemia [2]. Haemoglobin levels vary by the general health of a person, sex, age, physiological status, race, altitude, and levels of activity.

Common causes of anaemia include iron and other dietary deficiencies, parasitic infections like helminths and plasmodium malariae, inherited blood disorders like sickle cell anaemia, and other haemolytic conditions such as thalassemia. Other causes include direct bleeding, infectious diseases like tuberculosis, HIV, and other chronic inflammatory conditions. The World Health Organisation categorizes anaemia as a global public health problem, with more than $80 \%$ of countries having a prevalence of anaemia exceeding $20 \%$ of their populations [3]. Anaemia is much more prevalent in developing countries, where about $89 \%$ of the 1.93 billion anaemic people live [3]. Health consequences of anaemia include increased morbidity, reduced productivity, and reduced cognitive abilities $[4,5]$. 
Anaemia is a common haematological problem among people with HIV, and this makes it a public health challenge since the global burden of HIV is big, especially in developing countries $[6,7]$.

According to UNAIDS, more than 54\% of the 37.9 million people with HIV are within Eastern and Southern African countries [7]. According to The Uganda AIDS Country Progress Report of 2019, there are 1.3 million people with HIV in Uganda [8]. Anaemia is said to be prevalent in $1.3-95 \%$ of the people living with HIV depending on gender, age, pregnancy status, the stage of HIV disease, and the definition of anaemia $[9,10]$. Anaemia is a common haematological disorder of HIV infection, and in communities like that of Uganda, where other factors like malaria endemicity, poverty, and helminth infections are prevalent, the burden of anaemia in HIV infection is likely to be even greater. In the Health Management Information System (HMIS) 095 tool at TASO Entebbe Laboratory, the records for 2016-2018 show that out of the 6032 Haemoglobins $(\mathrm{Hb})$ done, 10\% had $\mathrm{Hb}$ less than $11.0 \mathrm{~g} / \mathrm{dl}$, which is lower than the prevalence in the literature $[9,10,11]$. It was not known whether the prevalence in the HMIS the true burden of anaemia among HIV clients was who were receiving ART and other services from TASO Uganda Entebbe.

\section{Objective}

This study was conducted to determine the prevalence, type, severity, and determinants of anaemia among people living with HIV and AIDS who were receiving care from The AIDS Support Organisation, Entebbe, in Uganda.

\section{Materials and Methods}

The study aimed at determining the prevalence and identifying the types and factors associated with anaemia among the TASO, Entebbe HIV clients who were on ARVs. It was a cross-sectional and quantitative study. The AIDS Support Organisation is a local HIV and
AIDS service organization with eleven Centres in Uganda: TASO Entebbe being one of the busiest TASO Centres, registering about 28 new clients on ART daily. The Centre has laboratory services, a controlled data system, and an active ART clinic serving both the urban Entebbe Municipality and the nearby rural communities, including Islanders from Lake Victoria. The study population was approximately 6000 registered adults and children living with HIV and on ART from the TASO, Entebbe Centre. The minimum sample size (n) was calculated using Kish Leslie formula of 1965 for cross-sectional studies where $\mathrm{n}=(\mathrm{Z} 2 \mathrm{P}(1-\mathrm{P})) / \mathrm{e} 2 ; \mathrm{p}(0.5)$ is the estimated proportion of people living with HIV and having anaemia; $\mathrm{Z}$ is the standard $\mathrm{Z}$-Score and e (0.05) the acceptable margin of error. The minimum sample size calculated was 385 people living with HIV. The minimum sample was increased by about $62 \%$ to 624 respondents in order to improve precision, identify any outliers which could skew the data, and enable comparisons among sub-groups considering the fact that gender, age, and social-economic variables are known to affect the prevalence of Anaemia [12]. TASO Entebbe has 4 clinic days in a week. Two clinics are general; one is for adolescents and one for prevention of motherto-child transmission (PMTCT). The appointment list for each of the four clinic days in a week was used as a sampling frame to systematically select a minimum of 13 clients each day for a period of 3 months from May to July 2019, resulting in a sample of 624 . Quantitative data from each Respondent was collected using a questionnaire, and a check list identified the clients' ART combination and the most recent viral loads. Each respondent's weight and height were used to calculate their BMI which was used as a proxy for nutritional status [13]. Full blood count and haemoglobin measurements were done on venous blood drawn by a certified laboratory technologist. Data analysis was done using StataMP [15]. 


\section{Laboratory Procedure}

Venous blood was drawn with sterile needles into vacutainer tubes treated with Ethylenediaminetetraacetic acid (EDTA) to prevent clotting. The samples for each day were put in a batch and thereafter analysed before the end of the day. Each vacutainer tube was opened and put in a Fully Automated Humacount 60TS Three-Part Hematology Analyzer to do the hemoglobin and full blood count measurements. Hemoglobin concentration is one of the laboratory tests for diagnosing anaemia [14].

From each sample, a blood film was manually prepared and examined to ascertain the red blood cell (RBC) morphology in order to determine the types of anaemia among the Respondents. Every Respondent who was found anaemic was referred to the Clinicians for management.

\section{Statistical Analyses}

Epidata was used for data entry and StataMP 15 for data analysis. The threshold for statistical significance was set at the conventional p-value of $<0.2$ and $<0.05$ at bivariate and multivariable analyses, respectively. Odds Ratios were used to compare the relative Odds of occurrence of Anaemia given exposure to independent variables identified in the literature. The WHO cut off points for Anaemia at sea level were used in this study and these are presented in Table 1. The measured hemoglobin level for each participant was adjusted by $-2 \mathrm{~g} / \mathrm{l}$ since the altitude in Central Uganda is approximately 1000 meters above sea level $[15,16]$.

Table 1. Cut-off Points for anaemia at Sea Level in Grams per Litre and its Severity

\begin{tabular}{|l|l|l|l|l|}
\hline Respondent age & No anaemia & Mild & Moderate & Severe \\
\hline Children, 6-59 months & $\geq 110$ & $100-109$ & $70-99$ & $<70$ \\
\hline Children, 5-11 years & $\geq 115$ & $110-114$ & $80-109$ & $<80$ \\
\hline Children, 12-14 years & $\geq 120$ & $110-119$ & $80-109$ & $<80$ \\
\hline Non-pregnant women & $\geq 120$ & $110-119$ & $80-109$ & $<80$ \\
\hline Pregnant women & $\geq 110$ & $100-109$ & $70-99$ & $<70$ \\
\hline Men, 15 years and above & $\geq 130$ & $110-129$ & $80-109$ & $<80$ \\
\hline
\end{tabular}

Adapted from WHO [15].

\section{Ethics Approval and Consent to Participate}

Ethical approvals were obtained from the Uganda Christian University's Research Ethics Committee (UCUREC25/10/600/00057) and the TASO Research Ethics Committee (TASOREC/013/19-UG-REC-009). Written informed consent was obtained from every adult participant and from a parent or guardian for participants under 16 years old. The names of the participants were not captured on the questionnaires, and the presentation of findings were general to avoid the identification of the participants. 


\section{Results}

Table 2. Social Demographic Characteristics of Respondents and Frequency of Anaemia n=624

\begin{tabular}{|c|c|c|c|c|}
\hline Variable & \multicolumn{2}{|c|}{ Category } & Frequency $(\%)$ & Category with anaemia \\
\hline \multicolumn{5}{|l|}{ Age } \\
\hline $\bar{x}=36.50$ & \multicolumn{2}{|l|}{ Children } & $23(3.68 \%)$ & $10(43.48 \%)$ \\
\hline $\mathrm{SD}=11.17$ & \multicolumn{2}{|l|}{ Adults } & $601(96.32 \%)$ & $267(44.43 \%)$ \\
\hline \multirow{3}{*}{ Gender } & \multicolumn{2}{|l|}{ Male } & $201(32.21 \%)$ & $72(35.82 \%)$ \\
\hline & & Pregnant & $25(4.01 \%)$ & $10(40.00 \%)$ \\
\hline & Female & Not pregnant & $398(63.78 \%)$ & $195(48.99 \%)$ \\
\hline \multirow{4}{*}{ Marital status } & \multicolumn{2}{|l|}{ Married } & $290(46.48 \%)$ & $113(38.96 \%)$ \\
\hline & \multicolumn{2}{|c|}{ Divorced } & $94(15.06 \%)$ & $53(56.38 \%)$ \\
\hline & \multicolumn{2}{|c|}{ Never married } & $201(32.22 \%)$ & $95(47.26 \%)$ \\
\hline & \multicolumn{2}{|c|}{ Widowed } & $39(6.25 \%)$ & $16(41.02 \%)$ \\
\hline \multirow{2}{*}{ Residence } & \multicolumn{2}{|l|}{ Rural } & $270(43.27 \%)$ & $118(43.70)$ \\
\hline & \multicolumn{2}{|l|}{ Urban } & $354(56.73 \%)$ & $159(44.91 \%)$ \\
\hline \multirow{3}{*}{$\begin{array}{l}\text { Educational } \\
\text { level }\end{array}$} & \multicolumn{2}{|c|}{ No formal education } & $76(12.18 \%)$ & $30(39.5 \%)$ \\
\hline & \multicolumn{2}{|c|}{ Up to primary seven } & $287(45.99 \%)$ & $125(45.5 \%)$ \\
\hline & \multicolumn{2}{|c|}{$\begin{array}{l}\text { Secondary education \& } \\
\text { above }\end{array}$} & $261(41.83 \%)$ & $122(46.7 \%)$ \\
\hline \multirow{4}{*}{ Occupation } & \multicolumn{2}{|c|}{ Professional } & $45(7.21 \%)$ & $26(57.8 \%)$ \\
\hline & \multicolumn{2}{|c|}{ Self-employment } & $291(46.63 \%)$ & $103(35.4 \%)$ \\
\hline & \multicolumn{2}{|c|}{ Peasant } & $116(18.59 \%)$ & $61(52.6 \%)$ \\
\hline & \multicolumn{2}{|c|}{ Unemployed } & $172(27.56 \%)$ & $87(50.6 \%)$ \\
\hline \multirow{3}{*}{$\begin{array}{l}\text { Income per } \\
\text { month }\end{array}$} & \multicolumn{2}{|c|}{ Greater than $500,000 /=$} & $68(10.90 \%)$ & $28(41.2 \%)$ \\
\hline & \multicolumn{2}{|c|}{$100,000 /=$ to $500,000 /$} & $287(46.00 \%)$ & $117(40.8 \%)$ \\
\hline & \multicolumn{2}{|c|}{ Less than $100,000 /=$} & $269(43.11 \%)$ & $132(49.1 \%)$ \\
\hline \multirow{2}{*}{$\begin{array}{l}\text { Nutritional } \\
\text { Education }\end{array}$} & Yes & & $390(62.05 \%)$ & $184(47.2 \%)$ \\
\hline & No & & $234(37.05 \%)$ & $93(39.7 \%)$ \\
\hline Drintes alcohol & Yes & & $209(33.49 \%)$ & $82(39.42 \%)$ \\
\hline Drinks alcohol & No & & $415(66.51 \%)$ & $195(46.98 \%)$ \\
\hline Smolor & Yes & & $19(3.04 \%)$ & $9(47.4 \%)$ \\
\hline smoker & No & & $605(96.96 \%)$ & $268(44.3 \%)$ \\
\hline Viral & Suppress & & $541(86.70 \%)$ & $226(41.8 \%)$ \\
\hline suppression & Unsuppr & & $83(13.30 \%)$ & $51(61.45 \%)$ \\
\hline & $\begin{array}{l}\text { Under w } \\
\mathrm{kg} / \mathrm{m} 2)\end{array}$ & ht $(<18.5$ & $154(24.68 \%)$ & $75(48.70 \%)$ \\
\hline BMI & $\begin{array}{l}\text { Normal } \\
\mathrm{kg} / \mathrm{m} 2)\end{array}$ & $.5-24.9$ & $331(53.04 \%)$ & $152(45.92 \%)$ \\
\hline & Overwei & $(\geq 25 \mathrm{~kg} / \mathrm{m} 2)$ & $135(21.63)$ & $48(35.55 \%)$ \\
\hline & $\mathrm{TDF} / 3 \mathrm{TC}$ & $\mathrm{EFV}$ & $283(45.34 \%)$ & $110(38.9 \%)$ \\
\hline & $\mathrm{TDF} / 3 \mathrm{~T}$ & DTG & $156(25 \%)$ & $22(33.3 \%)$ \\
\hline $\begin{array}{l}\text { AR } 1 \\
\text { Combinations }\end{array}$ & $\begin{array}{l}\mathrm{AZT} / 3 \mathrm{~T} \\
\mathrm{ATRr} \text { or }\end{array}$ & $\begin{array}{l}\text { vith NVP or } \\
\text { V }\end{array}$ & $48(7.70 \%)$ & $27(56.25 \%)$ \\
\hline & Others & & $137(22.00 \%)$ & $61(44.52 \%)$ \\
\hline
\end{tabular}




\begin{tabular}{|l|l|l|l|}
\hline Period in & $<12$ months & $87(13.94 \%)$ & $42(48.28 \%)$ \\
\cline { 2 - 4 } $\begin{array}{l}\text { months on ART } \\
\text { in months } \bar{x}=68,\end{array}$ & $12-72$ months & $284(45.51 \%)$ & $130(45.77 \%)$ \\
\cline { 2 - 4 } SD $=49.32$ & $>72$ months & $253(40.54 \%)$ & $105(41.50 \%)$ \\
\hline Sickle cell & Yes & $4(0.64 \%)$ & $4(100 \%)$ \\
\hline
\end{tabular}

Data was collected from a randomly selected sample of 624 respondents. Respondents were on ART for a mean period of 68 months ( $\mathrm{SD}=$ 49.32). The majority of respondents (96\%) were aged above 15 years (Table 2). The mean age was 36.5 years with a standard deviation of 11.17 years. The respondents were predominantly female $(68 \%)$, of whom $6.35 \%$ were pregnant, $46.48 \%$ were married, and $15 \%$ were divorced.

There were more urban dwellers $(56.73 \%)$ than those from rural areas. Approximately $12 \%$ of the respondents had no formal education and were predominantly selfemployed (46.63\%). Most respondents earned between 100,000 and $500,000 /=$ (equivalent to approx. 3.7-135 USA $\$$ at a rate of $1 \$=3700$ Uganda Shillings) per month but $43 \%$ earned less than 100,000 shillings (about 3.7 USA \$) per month. Approximately $62.5 \%$ of the respondents had received nutritional education, and $66.51 \%$ did not drink alcohol. The majority of respondents (>96\%) did not smoke, and more than $86 \%$ had viral suppression. Approximately $24 \%$ of the respondents were underweight, and $21 \%$ were overweight based on the cut-off points by WHO.[50] The most frequent ART combinations were Tenofovir / Lamivudine / Efavirenz [TDF/3TC/EFV] (45.35\%) and Tenofovir/ Lamivudine/ Dolutegravir [TDF/3TC/DTG] (25\%). Approximately $7.7 \%$ of ART combinations contained Zidovudine. Most of the respondents had been on ART for a long time, with the mean duration being 68 months $(\mathrm{SD}=49.32)$. Participants found with sickle cell disease were not included in the further analysis because the disease is known to be associated with anaemia.

Table 3. Prevalence, Type by Red Blood Cell Morphology and Severity of Anaemia

\begin{tabular}{|l|l|l|}
\hline \multicolumn{2}{|l|}{ Red blood cell morphology $\mathrm{n}=624$} & Frequency $(\%)$ \\
\hline Normochromic and Normocytic & $347(55.60)$ \\
\hline \multirow{5}{*}{ Hypochromic } & Microcytic & $85(13.63)$ \\
\cline { 2 - 3 } & Normocytic & $163(26.12)$ \\
\cline { 2 - 3 } & Macrocytic & $29(04.65)$ \\
\cline { 2 - 3 } & $\begin{array}{l}\text { Total hypochromic } \\
\text { (anaemia prevalence) }\end{array}$ & $277(44.40)$ \\
\hline \multirow{2}{*}{ Shape } & Other shapes & $620(99.36)$ \\
\cline { 2 - 3 } & Sickle & $04(0.64)$ \\
\hline Anaemia severity $\mathrm{n}=277$ & Frequency & Percentage \\
\hline Mild & 150 & 54.15 \\
\hline Moderate & 113 & 40.80 \\
\hline Severe & 14 & 5.05 \\
\hline Total & 277 & 100 \\
\hline
\end{tabular}

The prevalence of anaemia, as seen in Table 3 , among the study respondents was $44.4 \%$ (277/624). The most frequent type of anaemia was hypochromic normocytic (26.22\%), followed by microcytic anaemia (13.63\%). Most of the anaemia was mild $(54.15 \%)$ or moderate $(40.80 \%)$. Severe anaemia accounted for $5.05 \%$ of the respondents. There were four 
respondents with sickle cell disease, and all of them had mild to moderate anaemia.

Table 4. Bivariate and Multivariate Analysis of Factors Associated with Anaemia at $80 \%$ and $90 \%$ Confidence Interval

\begin{tabular}{|c|c|c|c|c|c|}
\hline \multirow[t]{2}{*}{ Variable } & \multirow[t]{2}{*}{ Category } & \multicolumn{2}{|c|}{ Bivariate Analysis } & \multicolumn{2}{|c|}{ Multivariable Analysis } \\
\hline & & OR & p-value $[80 \% \mathrm{CI}]$ & AOR & p-value $\left[\begin{array}{lll}95 \% & \mathrm{CI}\end{array}\right]$ \\
\hline \multirow[t]{2}{*}{ Gender } & Male & $\operatorname{Ref}$ & - & $\operatorname{Ref}$ & - \\
\hline & Female & 1.684 & $* 0.003(1.343,2.112)$ & 1.830 & $* * 0.010(1.157,2.894)$ \\
\hline \multirow{4}{*}{$\begin{array}{l}\text { Marital } \\
\text { Status }\end{array}$} & Married & Ref & - & Ref & - \\
\hline & Divorced & 2.025 & $* 0.003(1.488,2.755)$ & 2.007 & $* * 0.007(1.206,3.342)$ \\
\hline & Never married & 1.404 & $* 0.068(1.107,1.781)$ & - & - \\
\hline & Widowed & 1.090 & $0.805(0.698,1.700)$ & - & - \\
\hline \multirow[t]{4}{*}{ Occupation } & Professional & Ref & - & Ref & - \\
\hline & Self-employed & 0.400 & $* 0.005(0.264,0.608)$ & 0.317 & $* * 0.001(0.156,0.644)$ \\
\hline & Peasant & 0.810 & $0.553(0.515,1.278)$ & - & - \\
\hline & Unemployed & 0.748 & $0.390(0.485,1.154)$ & - & - \\
\hline \multirow{2}{*}{$\begin{array}{l}\text { Nutritional } \\
\text { education }\end{array}$} & Yes & Ref & - & Ref & \\
\hline & No & 0.738 & $* 0.071(0.596,0.916)$ & 0.677 & $* * 0.041(0.465,0.984)$ \\
\hline \multirow{2}{*}{$\begin{array}{l}\text { Drinks } \\
\text { alcohol }\end{array}$} & Yes & $\operatorname{Ref}$ & - & $\operatorname{Ref}$ & - \\
\hline & No & $1 . .373$ & $* 0.066(1.100,1.712)$ & - & - \\
\hline \multirow{2}{*}{$\begin{array}{l}\text { Viral } \\
\text { suppression }\end{array}$} & Suppressed & Ref & - & $\operatorname{Ref}$ & - \\
\hline & Unsuppressed & 2.221 & $* 0.001(1.630,3.028)$ & 2.246 & $* * 0.003(1.312,3.846)$ \\
\hline \multirow[t]{3}{*}{ BMI } & Underweight & Ref & - & Ref & - \\
\hline & Normal & 0.894 & $0.568(0.696,1.149)$ & - & - \\
\hline & Overweight & 0.581 & $* 0.025(0.426,0.792)$ & 0.524 & $* * 0.012(0.315,0.870)$ \\
\hline \multirow{10}{*}{$\begin{array}{l}\text { ART } \\
\text { combination }\end{array}$} & $\mathrm{ABC} / 3 \mathrm{TC} / \mathrm{AT} \mathrm{Vr}$ & Ref & - & - & - \\
\hline & $\mathrm{ABC} / 3 \mathrm{TC} / \mathrm{EFV}$ & 1.600 & $0.530(0.613,4.179)$ & - & - \\
\hline & AZT/3TC/ATVr & 2.889 & $* 0.109(1.237,6.747)$ & - & - \\
\hline & AZT/3TC/EFV & 0.500 & $0.391(0.178,1.408)$ & - & - \\
\hline & $\mathrm{AZT} / 3 \mathrm{TC} / \mathrm{NVP}$ & 1.556 & $0.455(0.729,3.317)$ & - & - \\
\hline & TDF/3TC/EFV & 1.055 & $0.907(0.587,1.895)$ & - & - \\
\hline & TDF/3TC/NVP & 1.030 & $0.956(0.511,2.076)$ & - & - \\
\hline & TDF/3TC/DTG & 0.811 & $0.656(0.444,1.483)$ & - & - \\
\hline & TDF/3TC/ATVr & 1.250 & $0.695(0.603,2.591)$ & - & - \\
\hline & Other & 1.939 & $0.261(0.912,4.130)$ & - & - \\
\hline
\end{tabular}

At bivariate analysis and exploratory confidence level of $80 \%$, nine independent variables showed significant association with anaemia in clients of TASO-Entebbe. When multivariable analysis (Table 4) was conducted at a $95 \%$ confidence level, six independent variables were significant, and these were gender, marital status, occupation, nutritional education, viral suppression, and BMI. The females $[(\mathrm{AOR}=1.83,95 \% \mathrm{CI}=1.157,2.894)$, $\mathrm{P}=0.010]$ and the divorced $[(\mathrm{AOR}=2.007$, $95 \% \mathrm{CI}=1.206,3.342), \mathrm{P}=0.007]$ were more likely to be anaemic than the males and marrieds respectively. The respondents who were divorced $[(\mathrm{AOR}=2.007,95 \% \mathrm{CI}=1.206$, $3.342), P=0.007]$ were more likely to be anaemic than the males and marrieds, respectively. 
The self-employed [(AOR $=0.317,95 \% \mathrm{CI}$ $=0.156,0.644), P=0.001]$, those who had not received nutritional education $[(\mathrm{AOR}=0.677$, $95 \% \mathrm{CI}=0.465,0.984), \mathrm{P}=0.041]$ and the obese $[(\mathrm{AOR}=0.524,95 \% \mathrm{CI}=0.315,0.870)$, $\mathrm{P}=0.012$ ] were less likely to be anaemic than the professionals and those who had received nutritional education and the respondents with underweight respectively. Respondents without viral suppression were more likely to be anaemic than those with suppression [(AOR = $2.246,95 \% \mathrm{CI}=1.312,3.846), \mathrm{P}=0.003$ ].

The ART combination Zidovudine/ Lamivudine/ Atazanavir/ritonavir (AZT/3TC/ATVr), drinkers of alcohol, and the never-married independent variables were significant at bivariate but not at multivariable analysis.

Logistic regression to measure the relationship of anaemia and the period of respondents on ART showed that ART duration had a protective effect against anaemia though not statistically significant.

\section{Discussion}

Respondents were on ARVs for long periods (68 months; $\mathrm{SD}=49.32$ ], and this may partly explain the high proportion of viral suppression $(86.7 \%)$ [17, 18]. There were more females (68\%) among respondents in this study than in the Uganda HIV/AIDS Country Progress Report $(55.5 \%)$. This could have been so because the mean age in this study was 36.5 years (11.17 SD), and according to the Uganda country report, the age groups 15-44 have more HIV-infected women than older age groups [8]. Children in this study were about $4 \%$ in the sample, which was lower than in the report where HIV-infected children are about $7 \%$ of the total number of people living with HIV in Uganda [8]. This could have been due to the nature of the sampling of children in this study. Only the children who were sent to the laboratory for other tests were included in the study to avoid multiple pricks. Blood drawn from the children for other laboratory tests was also used to measure haemoglobin and to categorise the anaemia. The marrieds were a large proportion $(46.48 \%)$ of the sample, but they were not asked whether that was a second or higher marriage which was a limitation because the divorced, the widowed, second, and higher marriages are associated with a higher risk of HIV and anaemia [19, 20]. With more than $43 \%$ of respondents earning less than $100,000 /=$ per month, this suggested a low income compared to the average household expenditure in Uganda in 2018 which was 325,800/= Uganda Shillings [21]. Such low income does not allow people to access basic necessities, including a balanced diet, and this may increase their risk of anaemia. Literacy rates and self-employment rates corroborated the World Bank and Uganda Bureau of Statistics (UBOS) statistics showing literacy rates of $>77 \%$ and self-employment rates of $50 \%$ among Ugandans. Most of the selfemployed respondents were engaged in trading ${ }^{22,21}$ Prevalence of smoking in Uganda is generally low $(<5 \%)$, but alcohol consumption is high (>19 litres of pure alcohol per capita), and the study respondents had similar statistics with $3.04 \%$ smokers and $33.49 \%$ prevalence of alcohol drinkers. Although smoking and drinking alcohol are known determinants of health, both of these were not significantly associated with anaemia in this study [23, 24].

\section{Prevalence, Type, and Severity of Anaemia}

Using the WHO haemoglobin levels and an adjustment of $-2 \mathrm{~g} / \mathrm{l}$ for the mean altitude in Central Uganda, the prevalence of anaemia was found to be $44.4 \%$. This was higher than in the general Ugandan population, where anaemia is documented to be $32 \%$ among women aged 15 49.25 According to the World Health Organisation when anaemia prevalence is $>40 \%$ in a given community, that is classified as a severe public health problem [2].

The high prevalence of anaemia in HIV is consistent with findings from other studies [11, 
26-29]. Anaemia prevalence varies depending on contexts, and it is known to be higher in ART naïve People Living with HIV (PLWHA), although even with ART treatment, HIV infection is still associated with anaemia [30, 31]. In HIV infections, anaemia is known to be a significant predictor of progression to AIDS. It is also said to be associated with poorer outcomes of HIV infection as well as negatively affect the quality of life and productivity of PLWHA [32, 9, 31]. Before the use of ART, anaemia was known to be an independent predictor of survival, and its effects were likely to be worse in low-resourced environments [33]. Consistent use of ART is known to be associated with improvement in haemoglobin level and reduction of severe anaemia, regardless of the ART combination [34, 31].

Respondents in this study were on ART for a mean period of 68 (SD 49.32) months, and so it can reasonably be assumed that if they were ART naïve, the prevalence and possibly severity of anaemia would have been worse [35]. The type of anaemia most prevalent in this study was normocytic and hypochromic, which is most common in chronic infections like HIV, and it is referred to as anaemia of inflammation (AI) [36]. Anaemia in HIV is thought to be caused by blood loss due to opportunistic infections and neoplasms such as Kaposi Sarcoma and decreased red blood cell production in the context of the reduced lifespan of RBCs and resistance to erythropoietin, a hormone that stimulates the production of RBCs. Anaemia of inflammation generally ranges from mild to moderate as the case is in this study [37, 31].

Severe anaemia was about $5.05 \%$ of those anaemic in this study which is lower than what has been found in other low resource countries where it can be as high as 22\%.38 Severe anaemia is associated with poorer HIV outcomes, but the consistent use of ART leads to its reduced prevalence [31]. Of the 14 respondents with severe anaemia, 13 had microcytic anaemia, which implied iron deficiency, and all of them had viral suppression, a contradiction of what is documented that consistent use of ART reduces the probability of severe anaemia [34, 31]. The respondents with severe anaemia, 12/14, had normal BMI, suggesting that nutrition may not be a contributing factor but probably iron metabolism. Long-standing anaemia of inflammation may lead to iron deficiency anaemia due to the restriction of intestinal absorption of iron and progressive depletion of iron stores [37, 31].

\section{Determinants of Anaemia}

In this study, the females were more likely to be anaemic than males $[(\mathrm{OR}=1.83,95 \% \mathrm{CI}=$ $1.157,2.894), P=0.010]$. This is in agreement with many studies on anaemia in HIV.31,38,39 This also collaborates with anaemia in the general population where the prevalence is higher in females than in males. ${ }^{2}$ Women, especially those in reproductive age groups, are thought to be more prone to anaemia than men, partly because of the menstrual periods and the drain on iron reserves when they get pregnant. ${ }^{31}$ The divorced were more likely [ $(\mathrm{OR}=2.007$, $95 \% \mathrm{CI}=1.206,3.342), \mathrm{P}=0.007]$ to have anaemia perhaps because of the risk of HIV and also the fact that anaemia is higher among PLWHA who were previously married $[19,20]$. This may partly be explained by the known poor health outcomes which are associated with separation or divorce [40]. Higher-income and perhaps a higher standard of living may explain the lower prevalence of anaemia $[(\mathrm{OR}=0.317$, $95 \% \mathrm{CI}=0.156,0.644), \mathrm{P}=0.001]$ among the self-employed. This is in agreement with findings on anaemia in the general Ugandan population where anaemia decreases with an increasing level of wealth [25].

The lower prevalence of anaemia among respondents who had not received nutritional education $[(\mathrm{OR}=0.677,95 \% \mathrm{CI}=0.465$, $0.984), P=0.041$ ] was not unexpected given the fact that nutritional education at TASO is more often given to clients who are found to be 
malnourished and already anaemic. The respondents without viral load suppression were more than two times [ $(\mathrm{OR}=2.246,95 \%$ $\mathrm{CI}=1.312,3.846), \mathrm{P}=0.003]$ likely to be anaemic than the ones with viral suppression, and these findings were in agreement with the literature on the effect of HIV treatment on general health [31, 41-42]. Viral suppression is associated with reduced morbidity and mortality as well as longer life expectancy, and this may partly explain the lower prevalence of anaemia [43, 42]. Body Mass Index was used as a proxy for nutritional status in this study [44, 45].

The overweight in this study were less likely $[(\mathrm{OR}=0.524,95 \% \mathrm{CI}=0.315,0.870)$, $\mathrm{P}=0.012]$ to be anaemic than the underweight. Underweight is associated with a higher risk of other health issues, including anaemia [46]. The ART combinations at multivariate analysis were not significantly associated with anaemia, but at bivariate analysis, the combination AZT/3TC/ATVr was significantly associated with anaemia. In related literature, it is suggested that during the Highly Active Antiretroviral Treatment era, combinations with Lamivudine may not have been significantly associated with anaemia in HIV [47, 48]. Duration on ART was found to have a protective effect, but unlike in other studies, the effect was not statistically significant $[49,29]$. This study was conducted in only one TASO Centre, which is located in the better served central region of Uganda and so anaemia prevalence from the hard-to-reach areas may be worse.

\section{Conclusion}

The prevalence of anaemia among PLWHA accessing services from TASO-Entebbe, Uganda, was $44.4 \%$ which was higher than the documented prevalence of anaemia in the general Ugandan population where the prevalence among women of age group 15-49 is $32 \%$. Anaemia in this study was mostly mild $(54.15 \%)$ to moderate $(40.80 \%)$, anaemia of inflammation ( $>58 \%)$, and affecting women $(48.46 \%)$ more than men $(35.82 \%)$. Gender, viral suppression, nutritional status, nutritional education, marital status, and economic wellbeing were associated factors.

\section{Recommendations}

1. HIV/AIDS service providers should recognise anaemia as highly prevalent among PLWHA and devise strategies to manage it since it is known to be associated with poorer treatment outcomes.

2. The suppression rate of $>86 \%$ at TASO is close to the WHO 90:90:90 strategy. Efforts should be sustained to achieve the United Nations 95\% target for viral suppression in order to minimize the prevalence of anaemia.

3. Nutritional education should not be selectively administered to the very sick but rather to all clients, including the obese, who are at a higher risk of noncommunicable disease complications.

4. The counselling services to the PLWHA should strengthen the marital component in order to minimise divorce and separation, which are associated with a higher prevalence of anaemia.

\section{Conflict of Interest}

The authors declare that they have no competing interests.

\section{Suggestions for further research}

This study used WHO haemoglobin reference values as the standard. However, it was noted that most of the participants who were categorised as anaemic $(<12 \mathrm{~g} / \mathrm{dl})$ showed no symptoms of anaemia. This calls for further research to develop customized reference values to the Ugandan and other similar settings.

\section{Acknowledgement}

We thank Our Lady of Consolata Kisubi Hospital Laboratory staff for laboratory services support. The Program Center Manager 
of TASO Entebbe 2019, for permission and support to carry out the study at TASO Entebbe and for Uganda Christian University for ethical clearance and technical guidance. All the

\section{References}

[1] WHO. Haemoglobin concentrations for the diagnosis of anaemia and assessment of severity. WHO/NMH/NHD/MNM/11.1. 2011a. https://apps.who.int/iris/bitstream/handle/10665/858 39/WHO_NMH_NHD_MNM_11.1_eng.pdf.

[2] WHO. Worldwide prevalence of anaemia 1993 2005 WHO Global Database on Anaemia. 2008. https://apps.who.int/iris/bitstream/handle/10665/438 94/9789241596657_eng.pdf;jsessionid=D8A6BB53 2C215E958051 A421 AE7CE613? sequence $=1$.

[3] Kassebaum NJ. The Global Burden of anaemia. 2013.

https://www.sciencedirect.com/sdfe/pdf/download/ei d/1-s2.0-S0889858815001896/first-page-pdf.

[4] WHO. Anaemia. 2020a. https://www.who.int/health-

topics/anaemia\#tab=tab_1.

[5] Chaparro, CM., \& Suchdev, PS. anaemia epidemiology, pathophysiology, and etiology in low- and middle-income countries. Annals of the New York Academy of Sciences, 1450(1), 15-31. 2019. https://doi.org/10.1111/nyas.14092.

[6] Enawgaw B, Alem M, Melku M, et al., Prevalence and associated risk factors of anaemia among HIV infected children attending Gondar university hospital, Northwest Ethiopia: a cross sectional study. BMC hematology, 15, 12. 2015. https://doi.org/10.1186/s12878-015-0032-6.

[7] UNAIDS. Global HIV Statistics. 2019a. https://www.unaids.org/sites/default/files/media_ass et/UNAIDS_FactSheet_en.pdf.

[8] UNAIDS. Uganda AIDS Country Progress Report July 2017-June 2018. 2019b. https://www.unaids.org/sites/default/files/country/do cuments/UGA_2019_countryreport.pdf.

[9] Belperio PS and Rhew DC. Prevalence and outcomes of anaemia in individuals with human immunodeficiency virus: a Systematic Review of the respondents are appreciated. Thank you, TASO Uganda Limited, for having allowed this study to be carried out on TASO Entebbe clients.

Literature. 2004 Am J Med 116(Suppl7A):27S-43S. CrossRef Medline Google Scholar.

[10] Johannessen A, Naman E, Gundersen SG. et al. Antiretroviral treatment reverses HIV-associated anaemia in rural Tanzania. BMC Infect Dis 11, 190 (2011). https://doi.org/10.1186/1471-2334-11-190.

[11] Melese H, Wassie MM, Woldie H, et al., anaemia among adult HIV patients in Ethiopia: a hospital-based Cross-sectional study. HIV/AIDS (Auckland, N.Z.), 9, 25-30. 2017 https://doi.org/10.2147/HIV.S121021.

[12] World Health Organization. Strategies to Prevent anaemia, recommendation from an expert group consultation. 2015. www.who.int 20 Avenue Appia, 1211 Geneva 27, Switzerland.

[13]FAO. Nutritional Status Assessment and Analysis Nutritional Status Indicators Learner Notes.

2007.

http://www.fao.org/elearning/course/fn/en/word/trai nerresources/learnernotes0282.doc.

[14]DeMaeyer EM, Dallman P, Gurney JM, et al., World Health Organization. Preventing and Controlling Iron Deficiency Anaemia Through Primary Health Care. A guide for Health Administrators and Program Managers. 1989. https://www.who.int/nutrition/publications/micronut rients/anaemia_iron_deficiency/9241542497.pdf (accessed on 25th September 2020).

[15]WHO. Haemoglobin concentrations for the diagnosis of anaemia and assessment of severity. Vitamin and Mineral Nutrition Information System. Geneva, World Health Organization. 2011b. (WHO/NMH/NHD/MNM/11.1)

http://www.who.int/vmnis/indicators/haemoglobin pdf, accessed [19th September 2020].

[16]GOV.UG. Uganda at a glance; Facts and Figures. n.d. https://www.gou.go.ug/content/factsfigures.

[17]Lokpo SY, Ofori-Attah P, Ameke LS, et al., "Viral Suppression and Its Associated Factors in 
HIV Patients on Highly Active Antiretroviral Therapy (HAART): A Retrospective Study in the Ho Municipality, Ghana”, AIDS Research and Treatment, vol. 2020, Article ID 9247451, 7 pages, 2020. https://doi.org/10.1155/2020/9247451.

[18] McMahon JH, Elliott JH, Bertagnolio S, et al., Viral suppression after 12 months of antiretroviral therapy in low- and middle-income countries: a systematic review. Bulletin of the World Health Organization, 91(5), 377-385E. 2013. https://doi.org/10.2471/BLT.12.112946.

[19] Nalugoda F, Guwatudde D, Bwaninka JB, Makumbi FE, Lutalo T, Kagaayi J, Sewankambo NK, Kigozi G, Serwadda DM, Kong X, Wawer MJ, Wabwire-Mangen F, \& Gray RH. (2014). Marriage and the risk of incident HIV infection in Rakai, Uganda. Journal of Acquired Immune Deficiency Syndromes (1999), 65(1), 91-98. https://doi.org/10.1097/QAI.0b013e3182a7f08a.

[20] Walque, DD, \& Kline R. The association between remarriage and HIV infection in 13 subSaharan African countries. Studies in family planning, $\quad 43 \quad 1, \quad 1-10.2012$. https://doi.org/10.1111/j.1728-4465.2012.00297.x.

[21]UBOS. Statistical Abstract. 2018. https://www.ubos.org/wpcontent/uploads/publicatio ns/05_2019STATISTICAL_ABSTRACT_2018.pdf. [22] The World Bank. Literacy rate, adult total (\% of people ages 15 and above). From: https://data.worldbank.org/indicator/SE.ADT.LITR. ZS. 2020.

https://www.who.int/nutrition/publications/micronut rients/anaemia_iron_deficiency/9789241596657/en/

Accessed on the 26th of May 2020.

[23]WHO. Global status report on alcohol and health. 2018a.

https://apps.who.int/iris/bitstream/handle/10665/274 603/9789241565639-eng.pdf?ua=1.

[24] $\mathrm{MOH}$. Global adult tobacco survey: country report 2013.2013. https://www.health.go.ug/sites/default/files/GATS\% 20Uganda\%20Country\%20Report\%20Final.pdf. [25] UBOS. Demographic and Health Survey. 2016. https://www.dhsprogram.com/pubs/pdf/FR333/FR33 3.pdf.
[26] Kyeyune R, Saathoff E, Ezeamama AE. et al. Prevalence and correlates of cytopenias in HIVinfected adults initiating highly active antiretroviral therapy in Uganda. BMC Infect Dis 14, 496. 2014. https://doi.org/10.1186/1471-2334-14-496.

[27] Mugisha JO, Shafer LA, Van der Paal L, et al., Aneamia in a rural Ugandan HIV cohort: prevalence at enrolment, incidence, diagnosis, and associated factors. Medical Research Council (MRC/UVRI) Uganda Research Unit on AIDS, Entebbe, Uganda. 2008.

[28]Denue BA, Kida IM., Hammagabdo A, et al., Prevalence of anaemia and Immunological Markers in HIV-Infected Patients on Highly Active Antiretroviral Therapy in North-eastern Nigeria. Infectious diseases, 6, 25-33. 2013. https://doi.org/10.4137/IDRT.S10477.

[29] Owiredu WKBA, Quaye L, Amidu N, AddaiMensah O. Prevalence of anaemia and immunological markers among Ghanaian HAARTnaïve HIV-patients and those on HAART. Afr Health Sci. 2011;11(1):2-15.

[30] Tamir Z, Alemu J, \& Tsegaye A. anaemia among HIV Infected Individuals Taking ART with and without Zidovudine at Addis Ababa, Ethiopia. Ethiopian journal of health sciences, 28(1), 73-82. 2018. https://doi.org/10.4314/ejhs.v28i1.9.

[31] Volberding PA, Levine AM, Dieterich D, et al., Clinical Impact and Evidence-Based Management Strategies, Clinical Infectious Diseases, Volume 38, Issue 10, 15 May 2004, Pages 1454-1463, 2004. https://doi.org/10.1086/383031.

[32] Gebremedhin KB and Haye TB. 2019. Factors Associated with anaemia among People Living with HIV/AIDS Taking ART in Ethiopia. 2019. https://www.hindawi.com/journals/ah/2019/9614205 I.

[33]Lundgren JD and Mocroft A. anaemia and Survival in Human Immunodeficiency Virus. Clinical Infectious Diseases 37(Suppl 4): S297-303 2003.

https://academic.oup.com/cid/article/37/Supplement _4/S297/311072.

[34] Maskew M, Brennan AT, Sanne I, et al., 2013. anaemia among HIV-Infected Patients Initiating Antiretroviral Therapy in South Africa: 
Improvement in Hemoglobin regardless of Degree of Immunosuppression and the Initiating ART Regimen.

From:

https://www.hindawi.com/journals/jtm/2013/162950 /.

[35] Woldeamanuel GG, Wondimu DH. Prevalence of anaemia before and after initiation of antiretroviral therapy among HIV infected patients at Black Lion Specialized Hospital, Addis Ababa, Ethiopia: a cross sectional study. BMC Hematol 18, 7. 2018. https://doi.org/10.1186/s12878-018-0099-y. [36] Weiss G, Ganz T and Goodnough LT. 2019. anaemia of inflammation: Iron Metabolism and Its Disorders January 3, $2019 . \quad$ From: https://ashpublications.org/blood/article/133/1/40/66 17/ANAEMIA-of-inflammation.

[37] Ganz. T. Molecular pathogenesis of anaemia of chronic disease. 2005. https://onlinelibrary.wiley.com/doi/full/10.1002/pbc. 20656.

[38] Makubi A, Okuma J, Spiegelman D, et al., Burden and Determinants of Severe anaemia among HIV-Infected Adults: Results from a Large Urban HIV Program in Tanzania, East Africa. 2013. https://journals.sagepub.com/doi/10.1177/23259574 13488195\#bibr4-2325957413488195.

[39] Jaganath D, Walker AS, Ssali F, et al., DART Trial, \& ARROW Trial. HIV-associated anaemia after 96 weeks on therapy: determinants across age ranges in Uganda and Zimbabwe. AIDS research and human retroviruses, 30(6), 523-530. 2014. https://doi.org/10.1089/aid.2013.0255.

[40] Sbarra DA. (2015). Divorce and health: current trends and future directions. Psychosomatic medicine, 77(3), 227-236. https://doi.org/10.1097/PSY.0000000000000168.

[41]NIH. 10 Things to Know About HIV Suppression. 2020. https://www.niaid.nih.gov/diseases-conditions/10things-know-about-hiv-suppression.

[42] May MT, Gompels M, Delpech V, et al., UK Collaborative HIV Cohort (UK CHIC) Study. Impact on the life expectancy of HIV-1 positive individuals of $\mathrm{CD} 4+$ cell count and viral load response to antiretroviral therapy. AIDS (London,
England), 28(8), 1193-1202. 2014 https://doi.org/10.1097/QAD.0000000000000243. [43]WHO. 2018b. Viral suppression for HIV treatment success and prevention of sexual transmission of HIV. From: https://www.who.int/hiv/mediacentre/news/viralsupression-hiv-transmission/en/.

[44]Bailey KV1 \& Ferro-Luzzi A. Use of body mass index of adults in assessing individual and community nutritional status. 1995. http://europepmc.org/backend/ptpmcrender.fcgi?acci $\mathrm{d}=$ PMC2486816\&blobtype $=$ pdf.

[45] WHO. 2020b. Body mass index - BMI. From: https://www.euro.who.int/en/health-topics/diseaseprevention/nutrition/a-healthy-lifestyle/body-massindex-bmi.

[46] WHO.

Malnutrition.

2020c.

https://www.who.int/news-room/fact-

sheets/detail/malnutrition.

[47] Semba RD, Shah N, Klein RS, et al.,, Human Immunodeficiency Virus Epidemiology Research Study Group, Prevalence and Cumulative Incidence of and Risk Factors for anaemia in a Multi-center Cohort Study of Human Immunodeficiency VirusInfected and -Uninfected Women, Clinical Infectious Diseases, Volume 34, Issue 2, 15 January 2002, Pages 260-266, https://doi.org/10.1086/338151.

[48]Richard MD and Darrell F. Anaemia in HIVinfected patients receiving highly active antiretroviral therapy. Journal of acquired immune deficiency syndromes (1999), 29(1), 54-57. 2002. https://doi.org/10.1097/00042560-20020101000007.

[49] Yesuf T, Muhie OA, Shibru H. Prevalence and predictors of anaemia among adult HIV infected patients at the University of Gondar Hospital, Northwest Ethiopia. HIV AIDS (Auckl). 2019; 11:211-217 https://doi.org/10.2147/HIV.S209446.

[50]WHO. 2000. Obesity: preventing and managing the global epidemic Report of a WHO Consultation (WHO Technical Report Series 894). https://www.who.int/nutrition/publications/obesity/ WHO_TRS_894/en/. 